\title{
LAND USE/COVER CHANGES RELATED TO FOREST COVER IN THE APUSENI MOUNTAINS NATURAL PARK. ROMANIA
}

DOI: http://dx.doi.org/10.18509/GBP.2020.93

UDC: 911.52:630]:502.171(498)

\author{
Monica Dumitraşcu ${ }^{1}$ \\ Roxana Cuculici ${ }^{2}$ \\ Ines Grigorescu ${ }^{1}$ \\ Cristina Dumitrică ${ }^{1}$ \\ Alexandra Vrînceanu ${ }^{1}$ \\ ${ }^{1}$ Institute of Geography, Romanian Academy, Bucharest - Romania \\ ${ }^{2}$ Faculty of Geography, University of Bucharest, Bucharest - Romania
}

\begin{abstract}
Following the social and economic transformations of the past decades, forest cover in Romania was seriously impacted, particularly in mountain areas. The study is seeking to analyze the spatio-temporal forest cover changes in Apuseni Mountains Natural Park. The study area is located in the north-west of Romania, covering a large part of the Western Carpathians. It includes extended forest ecosystems (72\%), pastures and grasslands, karst forms and phenomena, and a large variety of flora and fauna. The spatial and statistical analyses relay on LANDSAT satellite images (1990, 2000, 2018) aimed at assessing forest flows, conversion, and dynamics using some relevant landscape metrics (binary change index and trend index). Despite the protected area status, over the analyzed interval, forests recorded a slight decrease (4.3\%); pastures and grasslands being the main categories forests were converted to, but also the main categories converted into forests, followed by scrub and/or herbaceous vegetation. Forest cover evaluations in protected areas are critical in understanding the spatial dimension of landscape dynamics, and the resulted environmental disturbances in order to perform further evaluations on ecosystem services, risk assessment etc.
\end{abstract}

Keywords: forest cover, landscape metrics, Apuseni Mountains Natural Park, protected areas, Romania.

\section{INTRODUCTION}

Land use/cover change have become the main component of global change through their unprecedented consequences on local, regional, and global climate processes, biodiversity, ecosystems and the services they provide $[1,2,3,4]$. In protected areas, in particular, land use/cover changes are likely to cause habitat fragmentation and biodiversity loss that can negatively affect ecosystem processes both inside and outside their limits [5]. The changes related to forest cover are often associated with the natural, socio-economic, political, institutional and environmental drivers and involve both afforestation and deforestation. The latter, is generating forest losses due to natural disturbances (e.g. droughts, strong wind, landslides, insects attacks) and human intervention (e.g. harvesting). Under the resulted changes, ever since 1998, within the European Union (EU), a Forestry Strategy was adopted having as key principles the 
sustainable forest management and the multifunctional role of forests ${ }^{9}$. This was completed by the expanding of the protected areas surface though Natura 2000 network the foremost instrument in the European Union to maintain habitats and species in a favourable status, to support biodiversity ${ }^{10}$ and achieve the EU 2020 biodiversity targets ${ }^{11}$.

The Carpathian Chain is of outstanding importance for nature conservation which remained relatively undisturbed compared to Western Europe due to its rich biodiversity and habitats that provides a refuge for large mammal populations [6]. Here, the landscape and ecosystems transformations have varied thorough time in relation to the underlying driving factors. Thus, over the past 250 years, forest cover increase was the most common land-cover change [3], but with significant differences between regions and the different historical periods. For instance, in the northern Carpathians (cross Czech Republic, Poland, Slovakia and Ukraine) increase in forest cover was selective and occurred on areas less suitable to agriculture (higher and steeper) [7]. On the other hand, in the Romanian Carpathians, during the communist period (1945-1990), forest cover loss prevailed and was generally associated to tourism and industrial development [8], while after 1990, selective logging for household needs, illegal harvesting, and even large scale clear-cuts due to ambiguities in the forest laws led to large forest losses $[2,6]$.

In Romania, the fall of the communist regime (1989) brought about significant socioeconomic and political transformations which marked the changeover from the centralised to the free market system, mainly through privatisation and restitution of agricultural and forest land [9,10]. One important consequence was the expansion of private ownership over the former collective and state property (characteristic of the communist period). This change of property gave birth to a variety of landscape transformations related to land use/cover changes [2,9,10,11]. To these, other environmental challenges were added: the increasing occurrence and magnitude of extreme weather events, biodiversity loss, habitat fragmentation, trans-boundary pollution, trade of the endangered species, waste management [12] and spread of invasive/alien species [13]. Forest cover was one of the main land use category to be significantly affected, mainly through forest fragmentation and forest loss (deforestation). The majority of detected forest losses are related to the logging that occurred mainly in the mountain units [14]. In contrast, some expansion of the forest area has been recorded in relation to the natural regeneration, especially in the mountain and hilly regions [10] and artificial reforestation, strictly associated with the financial sources [15].

After the EU accession (2007), a greater emphasis was put on nature conservation through new regulations to increase the share of protected areas and new land management regulations, such as a requirement for management plans for private forests [16]. Thus, an increase of natural protected areas through the inclusion of new surfaces into Natura 2000 network was registered [17]. Consequently, in order to protect the natural environment in the Romanian Carpathians, a network of natural protect areas has been set, which was made of: 22 major protected areas totalizing around 1 million hectares, of which 12 national parks, 8 natural parks, 2 geoparks, as well as some 600 reserves and natural monuments totalling over 50,000 hectares $[12,17,18]$.

\footnotetext{
${ }^{9} \mathrm{https}$ ///ec.europa.eu/environment/forests/fpolicies.htm

${ }^{10} \mathrm{https}$ ://ec.europa.eu/environment/nature/climatechange/pdf/Guidance\%20document.pdf

${ }^{11} \mathrm{https} / / /$ ec.europa.eu/environment/nature/info/pubs/docs/nat2000newsl/nat32_en.pdf
} 
Studies carried out at national and regional level revealed the strong relationship between the forest cover transformations and a series of driving forces of change which have evolved together with the dynamics of natural, socio-economic and political environment, some applied in forest protected areas. Some examples refer to: privatisation and restitution processes [6,16,19], forest management [4], natural disturbances [20], complex human-induced impacts [12]. The resulted spatial and structural changes were generally addressed using Geographic Information System (GIS) and various statistical analyses based on topographic maps [21,22], satellite images [2,19,23] or CORINE Land Cover Database [10,14,15,21]. National-level studies highlighted the general trends in forest cover dynamics in relation to the overall land use/land cover transitions [10], or to various explanatory variables to predict future dynamics [14]. In turn, regional-level studies provided a more accurate picture of the changes in relation to the specific drivers of each region under discussion. Thus, [23] analysed forest cover changes under forest ownership recovery and deforestation processes, combined with the effects of biotic and abiotic disturbances in Iezer Mountains (Southern Carpathians); [24] performed the quantification of economic pressure on forest cover change in the Parâng-Cindrel Mountains (Southern Carpathians); [21] assessed the long-term changes in forest cover in the South West Development Region; [25] modelled the dynamics of forest areas and the related economic impacts in Maramureș County, while [26] assessed the economic pressure on the forest fund in the same County etc.

In protected areas, in particular, assessing forest cover changes are essential for the twofold role they play: forest ecosystems provide valuable services (e.g. provisioning, regulation) to nature and humans, while protected areas help protect these ecosystems. Studies on the relationship between forests and protected areas referred to the impacts of policy (i.e. forest restitution) [6] and management [27,28]; the value of forest ecosystem services under different management scenarios [29]; long-term forest conservation management [30,31]. Quantitative approaches on forest cover dynamics are quite limited in protected areas - [22] investigated land use/cover changes using spatial and statistical analysis in Putna Vrancea Natural Park. As a result, the main objective of the current study is to assess the specific trends in forest cover change within the last three decades in one of the foremost protected areas in Romania: Apuseni Mountains Natural Park.

\section{STUDY AREA}

Apuseni Mountains Natural Park is located in the north-west of Romania, covering a large part of the Western Carpathians (part of the Bihor Massif to the south and Vlădeasa Massif to the north) (Fig. 1). The surface of the park is 75,786 ha and goes beyond the administrative territory of three counties (Cluj, Bihor and Alba). It includes extended forest ecosystems (72\%), pastures and grasslands, karst forms and phenomena, and a large variety of flora and fauna [30,32].

The first proposals to declare Apuseni Mountains a protect area were made in the mid30s by the renown scientist Emil Racoviţă. Later on, several attempts to turn the area into a Natural Park were made, but it was in 1990 when Apuseni Natural Park was established by the Order no. 7/1990 regarding the establishment of 13 national parks in Romania, which was officially set by Law no. 5/2000 regarding the approval of the Plan of national territory management - Section III Protected Areas [32]. The management category the 
Park falls into is IUCN Category $\mathrm{V}^{12}$ : Protected Landscape/Seascape destined to the conservation of the local landscape and traditions, to protect the natural, spiritual and cultural heritage of the area, the sustainable management of the forests and to encourage the tourism based on these values. Following Romania's EU accession (2007) the surface of the park is proposed as Site of Community Importance (SCI) ROSCI0002 "Apuseni" and Special Protection Area (SPA) ROSPA0081 "Apuseni-Vlădeasa Mountains", within the European Ecological Network - Nature 2000.

The functional zoning of the Apuseni Mountains Natural Park was carried out bearing in mind the need to preserve biodiversity and landscape but also economic development. Thus, according to the legislation in force, four management areas were established [33]: the strictly protected area which includes areas with limited human influence, for which the priority objective is the protection and conservation of species, ecosystems and natural habitats; the full protected area comprising large areas less affected by human activities, of great importance in terms of biodiversity, habitat and landscape conservation; the sustainable management area that includes the area located outside the strictly protected area and the full protected area, where traditional and tourist activities unfold; the sustainable development of human activities area which covers the areas with the highest concentration of human activities (Fig. 1).

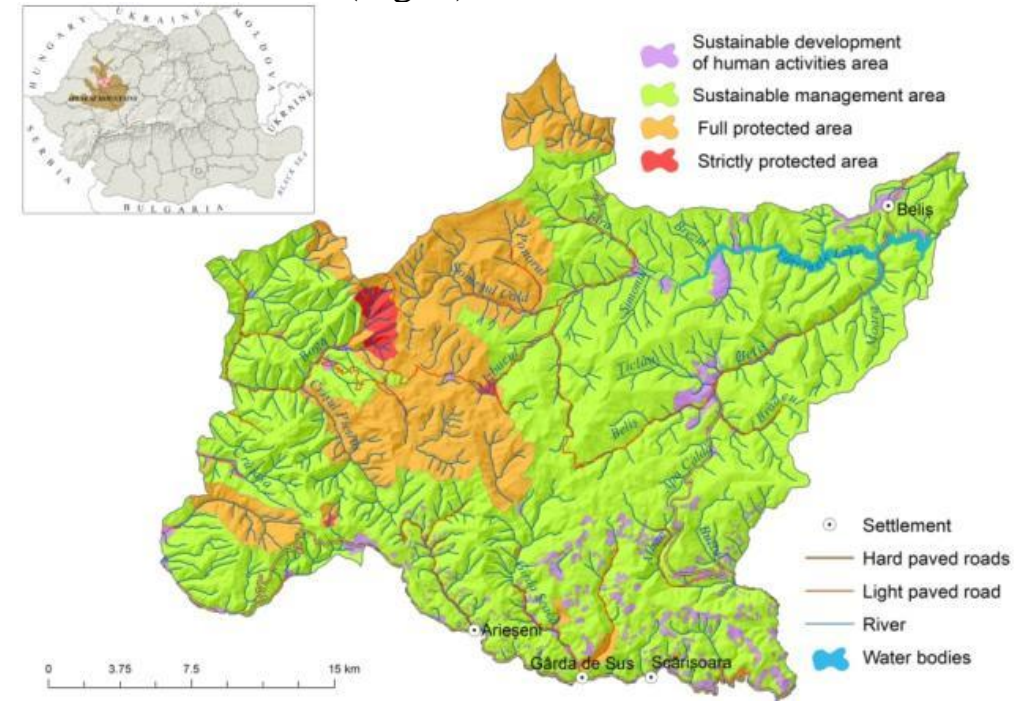

Figure 1. The location and zoning of the Apuseni Mountains Natural Park

Apuseni Natural Park is one of the most inhabited large protected areas in Romania with nearly 10,000 inhabitants in 55 permanent settlements (communes and villages). The settlements include the administrative territories of 16 communes (LAU according to EU nomenclature) and the properties of other 25 communes. The protected area is inhabited up to high altitudes where permanent and quasi-permanent settlements are located - e.g. the settlements of Ocoale - Scărişoara Plateau $(1200 \mathrm{~m})$ are among the highest settlements in the country.

The main economic activities are related to animal breeding, wood exploitation, mining, commerce, small industry and agriculture which is practiced up to an altitude of $1200 \mathrm{~m}$. It also includes rural settlements with specific architecture, ethnographic and folkloric

\footnotetext{
12 https://www.iucn.org/theme/protected-areas/about/protected-areas-categories/category-v-protectedlandscapeseascape
} 
traditions, most of them related to the local heritage represented by the so-called "wood civilization" which explains the long-term pressure on forests in the study area.

\section{METHODOLOGY AND DATA}

The analysis of the spatial and temporal forest cover changes in Apuseni Mountains Natural Park after the fall of communism (post 1990) was performed using spatial and statistical data. The spatial and statistical analyses relay on LANDSAT satellite images (1990, 2000, 2018) and the statistical data supplied by National Institute of Statistics (Tempo On-line 1990-2016, https://statistici.insse.ro/shop/) (Fig. 2).

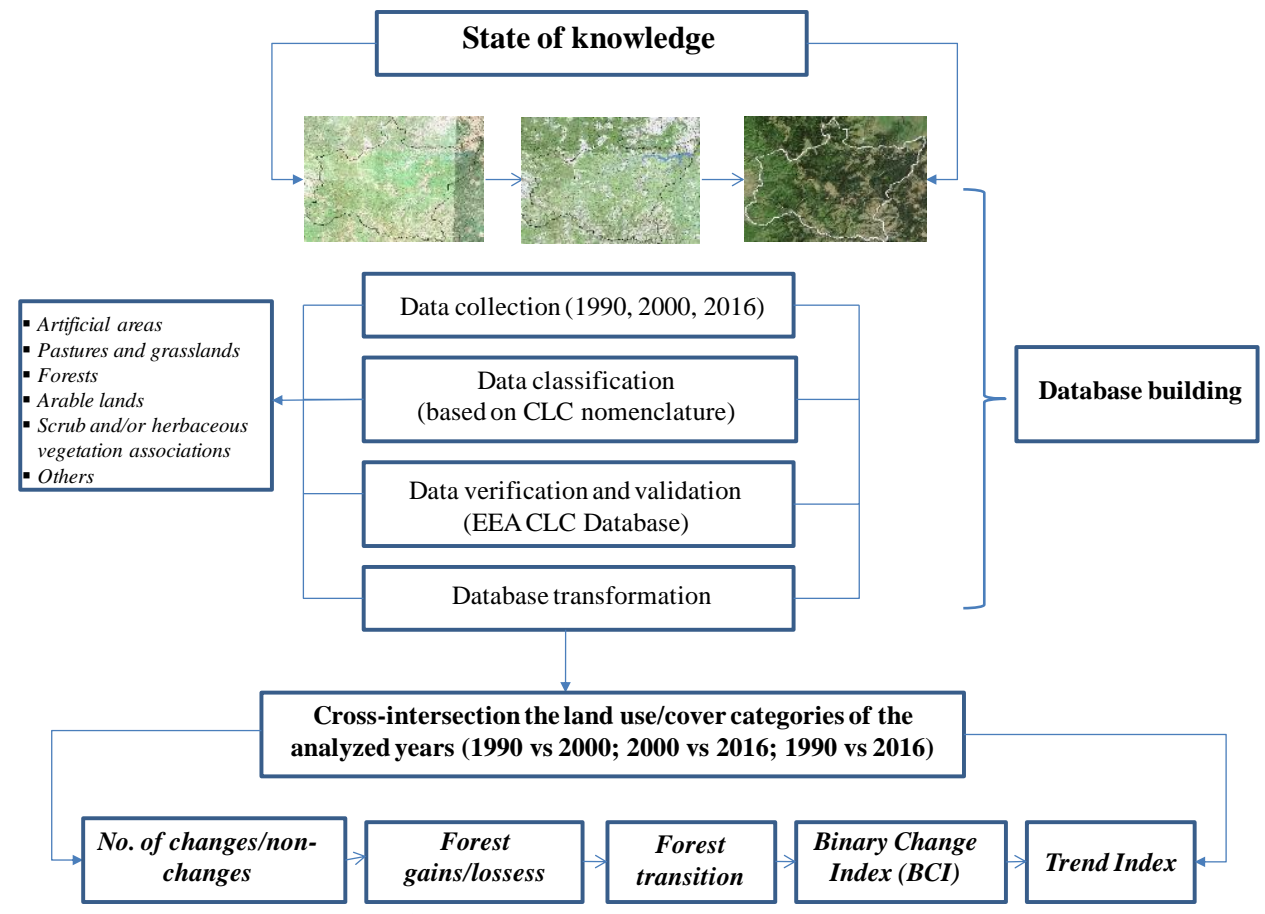

Figure 2. The methodological flow

Table 1. Land use/land cover categories analyzed

\begin{tabular}{|l|l|}
\hline $\begin{array}{l}\text { Land use/land cover } \\
\text { categories }\end{array}$ & CORINE nomenclature (level 3) \\
\hline $\begin{array}{l}\text { Arable lands (AL) } \\
\text { (inlc. Heterogeneous } \\
\text { agricultural areas) }\end{array}$ & $\begin{array}{l}\text { Non-irrigated arable land (211); Permanently irrigated land (212); Rice fields } \\
(213)\end{array}$ \\
\cline { 2 - 2 } & $\begin{array}{l}\text { Annual crops associated with permanent crops (241); Complex cultivation patterns } \\
(242) ; \text { Land principally occupied by agriculture, with significant areas of natural } \\
\text { vegetation (243) }\end{array}$ \\
\hline Artificial areas (AA) & $\begin{array}{l}\text { Continuous urban fabric (111); Discontinuous urban fabric (112); Industrial or } \\
\text { commercial units (121); Road and rail networks and associated land (122); Port } \\
\text { areas (123); Airports (124); Mineral extraction sites (131); Dump sites (132); } \\
\text { Construction sites (133); Green urban areas (141); Sport and leisure facilities (142) }\end{array}$ \\
\hline Vineyards and orchards (VO) & Vineyards (221); Fruit trees and berry plantations (222) \\
\hline Pastures and grasslands (PG) & Pastures (231); Natural grasslands (321) \\
\hline Forests (FR) & Broad-leaved forests (311); Coniferous forests (312); Mixed forests (313) \\
\hline $\begin{array}{l}\text { Shrub and/or herbaceous } \\
\text { vegetation associations (SH) }\end{array}$ & $\begin{array}{l}\text { Moors and heathland (322); Sclerophyllous vegetation (323); Transitional } \\
\text { woodland-scrub (324) }\end{array}$ \\
\hline Others (OTH) & Beaches, dunes, sands (331); Bare rocks (332); Sparsely vegetated areas (333) \\
\hline
\end{tabular}


The analysis was carried out using GIS-based methods and tools for the calculation of each analyzed land use/cover type grouped into the following major categories: arable lands (AL), artificial areas (AA), vineyards and orchards (VO), pastures and grasslands (PG), forests (FR), scrub and/or herbaceous vegetation associations ( $\mathrm{SH}$ ) and others $(\mathrm{OTH})(\mathrm{Tab} .1)$. Using the direct intersection method between layers and Raster Combine for rasters, the authors were able to compute the changes of each land use/cover category for the selected intervals (1990-2000, 2000-2016, 1990-2018).

As a result, based on the changed/unchanged ratio for each analyzed land use/cover category, several landscape metrics were computed: flows conversion [10,11,14], and dynamics using some relevant landscape metrics such as binary change index (BCI) and trend index $[21,22,34,35,36]$. Due to the unequal and sometimes incomplete information, the different mapping scales and the particular environmental features of the study area, the authors performed some database adjustments and normalization.

\section{RESULTS AND DISCUSSIONS}

The complex interactions between the biophysical conditions (climate, relief, lithology) are critical in the distribution and share of the different land use/cover categories, yet under the moderating effects of the anthropic activities. The continuous human impacts, since earliest times, have evolved and diversified under the recent socio-economic and political conditions of the post-communist period. In addition, similar to other mountain units, the land affected by erosion or landslides determined the development of specific vegetation which has changed the landscape structure and functionality [22].

The transformations that took place during the post-communist period set off a variety of processes which also involved restructuring in agriculture and forestry which, apart from the social and economic consequences, have changed the landscape. In mountains areas, forest cover was the main land use category to be targeted by the resulted spatial and functional changes, though deforestation and afforestation. Deforestation generally occurred through illegal loggings on private-owned small forest plots; the retrocession process having an important contribution to this process. On the other hand, afforestation was mainly due to natural regeneration on deforested terrains, on abandoned farmland and pastures and due to artificial reforestation (planting after logging, calamities or establishment of a new forest on degraded lands) [10]. The deforestation was mainly related to the transition of the forest into the shrub and/or herbaceous vegetation association, pastures, both classes representing the highest shares of total deforestationrelated transition [14]. Reducing the livestock during the post-communist period and the decrease of the pressure on the mountain meadows was linked to a slight natural extension of the forests and bushes to the upper forest limit. Although these have a low economic value, the effects on the ecosystem's balance are positive.

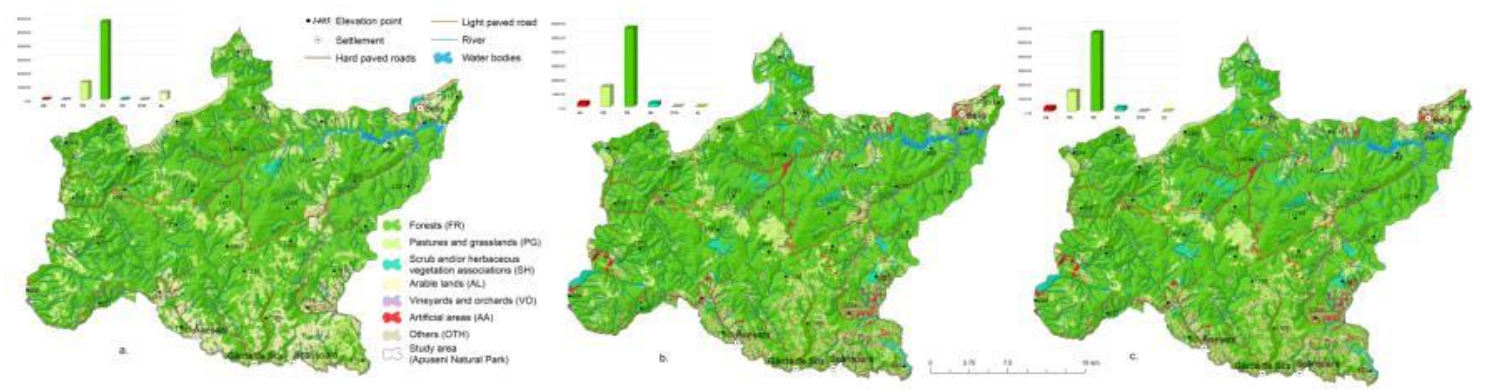

Figure 3. Main land use/cover categories in Apuseni Mountains Natural Park 
In the study area forests (FR) are the main land use category with around $75 \%$ of the territory, followed by natural pastures and grasslands (PG) with nearly $16 \%$ and arable lands (AL) with up to $6.8 \%$. However, among all land use/cover categories, AA, SH and AL were subject to spatial changes during the analysed period (Fig. 3).

During 1990-2000 period, the land reform of 1991 set off a continuous process of land restitution [9] when the foremost land use/cover changes occurred. Forest cover however, registered only a slight decrease due to the continuous attempts to transform the area into a natural park, the availability of other land resources to be subject to land transformation more easily (e.g. arable lands, pastures and grasslands, shrubs) or the difficulty of interpreting on satellite images the small-scale selective timber harvesting (regularly illegal) (Fig. 4).

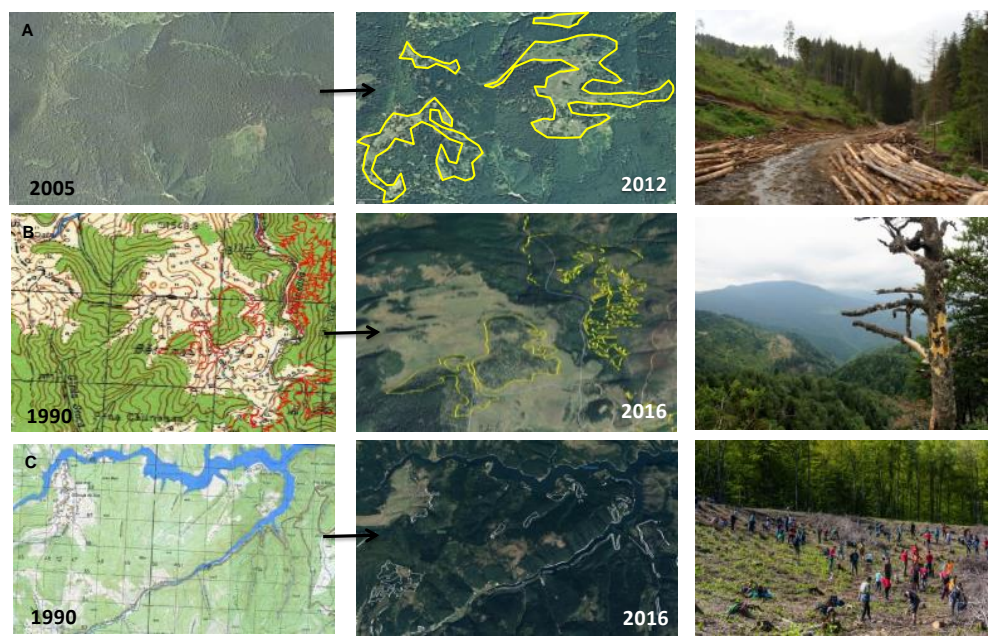

Figure 4. Examples of forest cover losses $(\mathrm{a}, \mathrm{b})$ and gains $(\mathrm{c})$

Since 2000, a large number of natural areas were declared protected and deforestation practices on their territory somehow diminished [14]. This is also the case of Apuseni Mountains Natural Park, where, during the 2000-2018 interval, forest cover registered a relatively low decrease, generally on areas affected by natural disturbances (e.g. landslides, strong winds, snow storms), selected harvesting (illegal logging) or the extension of infrastructure (e.g. transport, electricity, communication) driven by residential and touristic development.

Forest cover flows commonly show the gains and losses throughout the analyzed period. During the 1990-2000 interval, forest cover gains mainly occurred at the expense of arable lands (AL) and pastures and grasslands (PG), while the forest losses were to be replaced by other categories (OTH) and pastures and grasslands (PG). Over the 20002018 period, forest gains were at the expense of other categories $(\mathrm{OTH})$ and shrubs $(\mathrm{SH})$, whereas forest losses for pastures and grasslands (PG) and shrubs (SH). Overall, pastures and shrubs are the main land use/cover categories to be permanently subject to change in relation to forest cover dynamics (Fig. 5). 

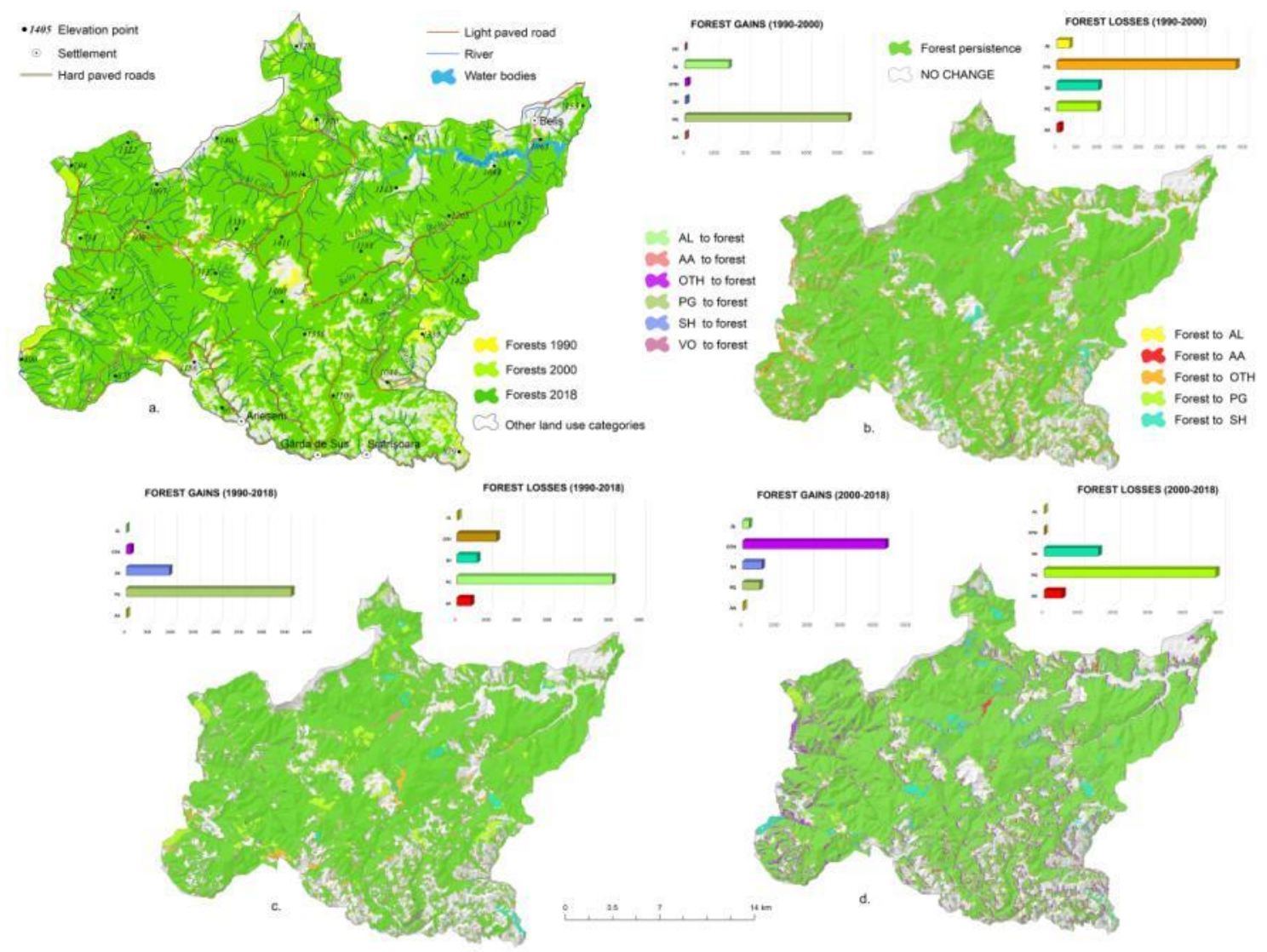

Figure 5. Forest cover dynamics 1990-2018

(a) and forest cover flows: 1990-2000 (b), 2000-2018 (c) and 1990-2018 (d)

According to the binary change index one can observe the areas the most affected/not affected by change in the forest cover. Most of changes occurred during the 1990-2000 interval in relation to the main political and legislative changes of the so-called transition period [9]. Visible fewer changes were registered during the 2000-2016 interval, mainly in relation to the establishment of the protected area status and the management measures which were undertaken in this respect (Fig. 6).

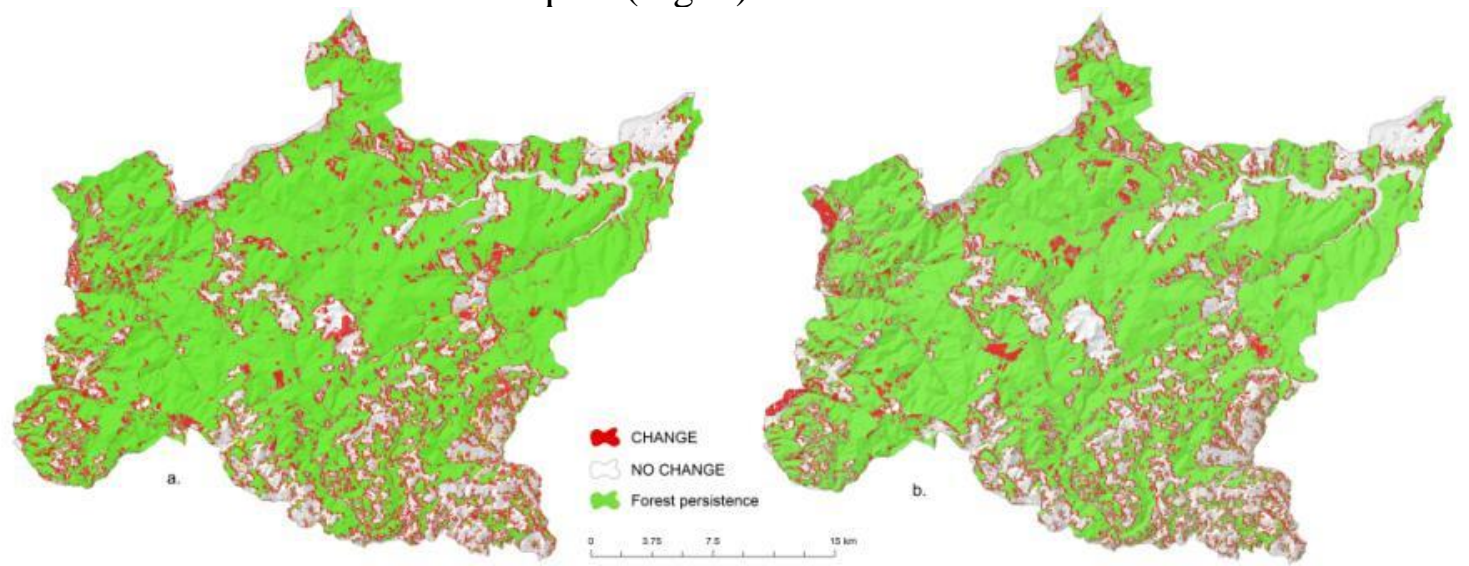

Figure 6. Forest cover changes using binary change index: 1990-2000 (a); 2000-2018 (b).

The trend index, which was computed as the number of changes (from one category to another) against the total number of changes registered at pixel level [22] shows that the most important changes took place with regard to artificial areas (AA), forests (FR), arable (AL) and others (OTH) in the 1990-2000 intreval and forests (FR), pastures \& 
grasslands (PG), artificial areas (AA) and others (OTH) over the 2000-2018 period (Fig. 7).

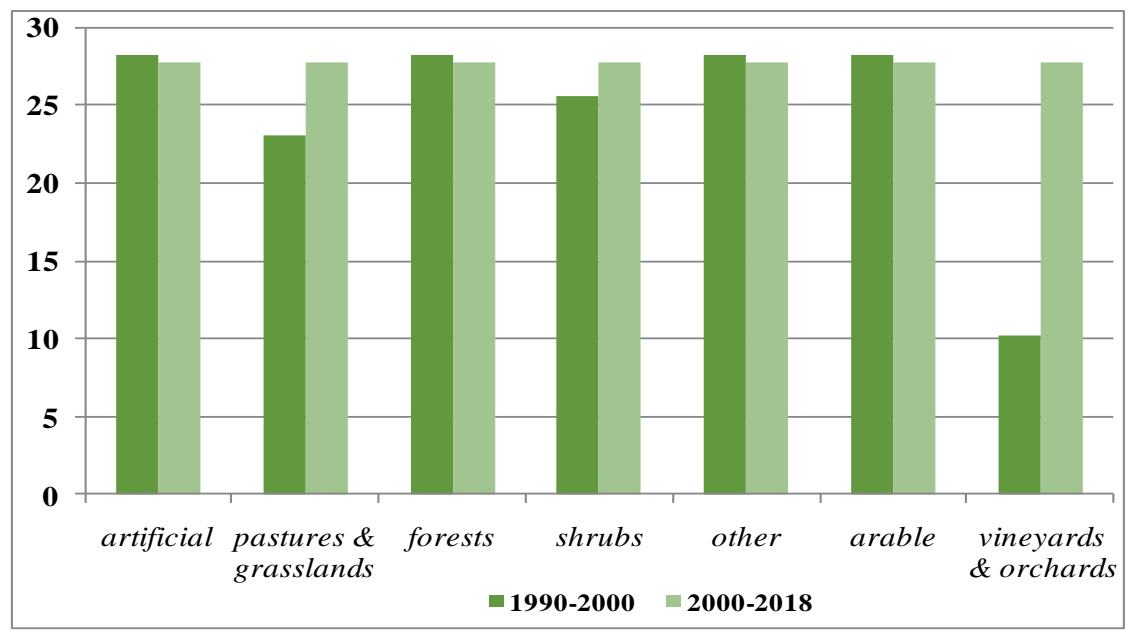

Figure 7. Trend index for the main land use/cover categories

The overall analysis based on the trend index pinpoints a greater diversity of the land use/cover categories subject to change. However, forest cover is at the centre of all changes during the two intervals and the most intense changes took place during the second period (2000-2018).

\section{CONCLUSIONS}

Forest cover evaluations in general and forest cover changes in protected areas, in particular, are critical in understanding the spatial dimension of landscape dynamics, and the resulted environmental disturbances (e.g. habitat fragmentation, watershed protection, land degradation). They can also be used in performing further evaluations on ecosystem services (e.g. carbon storage, climate regulation), risk assessment etc.

In Apuseni Mountains Natural Park, despite the protected area status, forests recorded an overall slight decrease (4.3\%) with differentiations between the analysed intervals. The forest cover flows analysis revealed that pastures \& grasslands (PG) are the main land use categories forests were converted to, but also the main categories converted into forests, followed by shrubs $(\mathrm{SH})$ and others $(\mathrm{OTH})$. According to the binary change index, most of changes occurred during the 1990-2000 interval in relation to the main political and legislative changes of the transition period, while less changes occurred between 20002016, mainly in relation to the establishment of the protected area and the management actions. The trend index shows that the largest amount of transformations took place with respect to forests (FR), artificial areas (AA), arable lands (AL) and pastures \& grasslands (PR) during both intervals.

Overall, forest cover changes (especially forest cover loss) have various effects and consequences on the environment such as: land and soil degradation, changes of the climatic patterns and climate change, biodiversity loss, habitats' fragmentation, shifting forest limit altitudes, biological pollution (sawdust) [12], but also carbon stock loss. Carbon in protected areas has strategic value for environmental conservation and for mitigation of climate change.

Measures and strategies that can be carried out to preserve forest cover, especially in protected areas habitually should be addressed at the strategic and political level (e.g. improvement of forest management; involvement of the local authorities and protected 
areas stuff in conserving the natural landscape, control of the illegal deforestations), through public awareness and education programs, as well as through international cooperation and partnerships with other countries from the Carpathian area.

\section{Acknowledgements:}

This work was supported by the project PN-III-P1-1.2-PCCDI-20170404/31PCCDI/2018 (UEFISCDI).

\section{REFERENCES}

[1] Foley, J. A., DeFries, R., Asner, G. P., Barford, C., Bonan, G., Carpenter, S. R., \& Helkowski, J. H. Global consequences of land use, Science, 309(5734), 570-574, 2005.

[2] Kuemmerle, T., Müller, D., Griffiths, P., \& Rusu, M. Land use change in Southern Romania after the collapse of socialism. Regional Environmental Change, 9(1), 1, 2009.

[3] Munteanu, C., Kuemmerle T., Boltiziar M., Van Butsic, Gimmi U., Halada L., Kaimh D., Királyi G., Konkoly-Gyurój E., Kozak J., Lieskovsky J., Mojses M., Müller D., Ostafinh K., Ostapowicz K. Shandra O., Stych P., Walker S., Radeloff V. C. Forest and agricultural land change in the Carpathian region-A meta-analysis of long-term patterns and drivers of change. Land Use Policy, http://dx.doi.org/10.1016/j.landusepol.2014.01.012, 2014.

[4] Munteanu, C., Nita, M. D., Abrudan, I. V., \& Radeloff, V. C. Historical forest management in Romania is imposing strong legacies on contemporary forests and their management. Forest Ecology and Management, 361, 179-193, 2016.

[5] Hansen, A. J., DeFries, R. Ecological mechanisms linking protected areas to surrounding lands. Ecological Applications, 17(4), pp. 974-988, 2007.

[6] Knorn, J., Kuemmerle, T., Radeloff, V. C., Szabo, A., Mindrescu, M., Keeton, W. S., Abrudan I., Griffiths P., Hostert, P. Forest restitution and protected area effectiveness in post-socialist Romania. Biological Conservation, 146(1), 204-212, 2012.

[7] Kozak, J., Estreguil, C., \& Troll, M. Forest cover changes in the northern Carpathians in the 20th century: a slow transition. Journal of Land Use Science, 2(2), 127-146, 2007.

[8] Huzui, A. E., Călin, I., \& Pătru-Stupariu, I. Spatial pattern analyses of landscape using multitemporal data sources. Procedia Environmental Sciences, 14, 98-110, 2012.

[9] Bălteanu, D., Popovici, E.A. Land use changes and land degradation in post-socialist Romania, Revue Roumaine de Géographie/Romanian Journal of Geography, 54 (2), 95-105, 2010.

[10] Popovici, E-A., Bălteanu, D., Kucsicsa, Gh. Assessment of changes in Land-Use and LandCover pattern in Romania using Corine Land Cover database, Carpathian Journal of Earth and Environmental Sciences, 8 (4), 195-208, 2013.

[11] Popovici, E. A., Kucsicsa, G., Balteanu, D., Grigorescu, I., Mitrica, B., Dumitrascu, M., \& Damian, N. Past and future land use/cover flows related to agricultural lands in Romania. An assessment using CLUE-S Model and CORINE Land Cover Database. Carpathian Journal of Earth and Environmental Sciences, 13(2), 613-628, 2018.

[12] Bălteanu, D., Năstase, M., Dumitraşcu, M., \& Grigorescu, I. Environmental Changes in the Maramureş Mountains Natural Park. In Sustainable Development in Mountain Regions (pp. 335348). Springer, Cham, 2016.

[13] Dumitraşcu Monica, Grigorescu Ines, Kuscicsa Gheorghe, Doroftei Mihai, Năstase Mihaela, Dragotă Carmen-Sofia, Invasive terrestrial plant species in the Romanian protected areas. A geographical approach. Romanian Journal of Geography, vol. 58 (2), pp. 145-160, Editura Academiei Române, Bucureşti, ISSN 1220 - 5311, 2014. 
[14] Kucsicsa, G., Popovici, E. A., Bălteanu, D., Grigorescu, I., Dumitraşcu, M., \& Mitrică, B. Future land use/cover changes in Romania: regional simulations based on CLUE-S model and CORINE land cover database. Landscape and Ecological Engineering, 15(1), 75-90, 2019.

[15] Dutcă, I., Abrudan, I.V. Estimation of Forest Land-Cover Change in Romania, between 1990 and 2006, Bulletin of the Transilvania University of Brasov, 3 (52), 33-36, 2010.

[16] Ioras, F., \& Abrudan, I. V. The Romanian forestry sector: privatisation facts. International Forestry Review, 8(3), 361-367, 2006.

[17] Geacu S, Dumitraşcu M, Maxim I. The evolution of the natural protected areas network in Romania, Romanian Journal of Geography, vol. 56 (1), 33-41, 2012.

[18] Bălteanu D., Dumitrşcu M., Ciupitu D., Geacu S., Natural protected areas în Romania. SpaceSociety-Environment, (Eds: Bălteanu D., Badea L., Niculescu Gh., Popescu C., Buza M., Dumitrascu M.), Editura Academiei Române, Bucureşti, pag. 328-340, 2006.

[19] Griffiths, P., Kuemmerle, T., Kennedy, R.E., Abrudan, I.V., Knorn, J., Hostert, P. Using annual time-series of Landsat images to assess the effects of forest restitution in post-socialist Romania, Remote Sens Environ, 118, 199-214. doi:10.1016/j.rse.2011.11.006, 2012.

[20] Prăvalie, R., Sîrodoev, R., Peptenatu, D. Changes in the forest ecosystems in areas impacted by aridization in south-western Romania, Journal of Environmental Health Science and Engineering, 12:2, (doi: 10.1186/2052-336X-12-2), 2014.

[21] Dumitraşcu, M., Grigorescu, I., Cuculici, R., Dumitraşcu, C., Năstase, M., \& Geacu, S. Assessing long-term changes in forest cover in the South West Development Region. Romania, Forum geographic, vol. 13, no. 1, pp. 76-85, 2014.

[22] Cuculici, R., Grigorescu, I., Dumitraşcu, M., Marin, E., \& Dumitraşcu, C. Assessing land use/cover changes in the Putna-Vrancea Natural Park. Romania. International Multidisciplinary Scientific GeoConference: SGEM: Surveying Geology \& mining Ecology Management, 17, 109116, 2017.

[23] Mihai, B., Săvulescu, I., Rujoiu-Mare, M., \& Nistor, C. Recent forest cover changes (20022015) in the Southern Carpathians: A case study of the Iezer Mountains, Romania. Science of the total environment, 599, 2166-2174, 2017.

[24] Marinescu, E., Marinescu, I. E., Vlăduţ, A., \& Marinescu, S. Forest Cover Change in the Parâng-Cindrel Mountains of the Southern Carpathians, Romania. In The Carpathians: Integrating Nature and Society Towards Sustainability (pp. 225-238). Springer, Berlin, Heidelberg, 2013.

[25] Pintilii, R. D., Andronache, I., Diaconu, D. C., Dobrea, R. C., Zeleňáková, M., Fensholt, R., Peptenatu D., Drăghici C.C., Ciobotaru, A. M. Using fractal analysis in modeling the dynamics of forest areas and economic impact assessment: Maramureș County, Romania, as a case study. Forests, 8(1), 25, 2017.

[26] Drăghici, C. C., Peptenatu, D., Simion, A. G., Pintilii, R. D., Diaconu, D. C., Teodorescu, C., Rapus R.M., Grigores A.M, Dobrea, C. R. Assessing economic pressure on the forest fund of Maramureș County-Romania. Journal of Forest Science, 62(4), 175-185, 2016.

[27] Stancioiu, P. T., Abrudan, I. V., \& Dutca, I. The Natura 2000 ecological network and forests in Romania: implications on management and administration. International Forestry Review, 12(1), 106-113, 2010.

[28] Knorn, J. A. N., Kuemmerle, T., Radeloff, V. C., Keeton, W. S., Gancz, V., Biriş, I. A., Svoboda M., Griffiths P., Hagatis A., \& Hostert, P. Continued loss of temperate old-growth forests in the Romanian Carpathians despite an increasing protected area network. Environmental Conservation, 40(2), 182-193, 2013.

[29] Popa, B., Pascu, M., Nita, D. M., Borz, S. A., \& Codreanu, C. The value of forest ecosystem services in Romanian protected areas-a comparative analysis of management scenarios. Bulletin 
of the Transilvania University of Brasov. Forestry, Wood Industry, Agricultural Food Engineering. Series II, 6(2), 53, 2013.

[30] Feurdean, A., \& Willis, K. J. The usefulness of a long-term perspective in assessing current forest conservation management in the Apuseni Natural Park, Romania. Forest Ecology and Management, 256(3), 421-430, 2008.

[31] Feurdean, A. N., Willis, K. J., \& Astaloş, C. Legacy of the past land-use changes and management on the 'natural'upland forest composition in the Apuseni Natural Park, Romania. The Holocene, 19(6), 967-981, 2009.

[32] Bălteanu D., Dumitrşcu M., Geacu S., Ciupitu D., Ariile naturale protejate. In România. Natură şi Societate (Eds: Bălteanu D., Dumitraşcu M., Geacu S., Mitrică B., Sima M.), Editura Academiei Române, Bucureşti, pp. 542-562, 2016.

[33] Plan de acțiune privind utilizarea durabilă a serviciilor ecosistemice din Parcul Natural Apuseni, http://www.interregdanube.eu/uploads/media/approved_project_output/0001/34/6ca13988230da50aa3e672105ac43 ff06a91d364.pdf, 2019.

[34] Pătru-Stupariu I., Stupariu M.S. Cuculici R., Landscape metrics for assessment of mountain landscape using GIS applications, Revista de Geomorfologie, 11, pp. 59-62, 2009.

[35] Pătru-Stupariu I., Stupariu M.S., Cuculici R. Huzui A., The contribution of global indicators to landscape change modeling. Case study: Prahova Valley (Romanian Carpathians and Subcarpathians), International Journal of Physical Sciences, 6(3), pp. 534-539, 2011.

[36] Stupariu M.S., Pătru-Stupariu I. Cuculici R., Geometric approaches to computing 3Dlandscape metrics. Landscape Online, 24, pp. 1-12, 2010. 